\section{Atopy, passive smoking, respiratory infections and asthma among children from kindergarten and elementary school}

\author{
Universidade Federal de São Paulo/Escola Paulista de Medicina, São \\ Paulo, Brazil.
}

\section{....... INTRODUCTION}

Smoking is a major public health issue due to its direct and indirect effects on health outcomes. ${ }^{1,2,3}$ It has been demonstrated that exposure to passive smoking (tobacco smoke) increases the incidence of coughing and otitis, as well as generating childhood asthma and bronchial hyper-responsiveness, acute bronchiolitis, lower respiratory tract infections and pneumonia. ${ }^{1,4,5,6}$ The number of smokers in the home and the quantity of cigarettes consumed has been correlated with the abovementioned health problems. In addition, a linear correlation has been shown between smoking mothers and respiratory disease in children. ${ }^{2,7}$

Passive smoking may affect children directly, by decreasing pulmonary function, or indirectly ${ }^{8,9}$ by increasing their exposure to infectious diseases, since smokers have a higher incidence of respiratory infections. ${ }^{1,2,3}$

Three cohort studies have demonstrated an increase in the frequency of respiratory diseases and hospital admissions among toddlers whose parents smoke. In Israel, a survey of 10,762 children aged less than one year old revealed 9.5 admissions due to bronchitis and pneumonia per 100 children whose mothers were non-smokers, in comparison with 13.1 admissions per 100 children with smoking mothers.

British researchers conducted a follow-up study on 2,205 children for 5 years and showed that the incidence of lower respiratory tract infection was increased in children of smoking mothers in comparison with children of non-smoking mothers. This incidence increased considerably when both parents smoked, even after adjusting for the number of members in the family, socioeconomic status and birth weight. ${ }^{2}$

A third cohort study conducted in New Zealand, with 1,265 children followed up for 3 years, exhibited the following results: maternal smoking was strongly related to bronchitis/pneumonia in the first year of life, and an increase of 5 cigarettes per day resulted in an increment of 2.5 to 3.5 cases of bronchitis/pneumonia for every 100 children at risk. ${ }^{3}$

The presence of smoking adults in the family increases the lengths of time spent in bed and activity restrictions among children. Disease duration (in days) increased according to the number of cigarettes smoked in the family. ${ }^{1}$

The aim of this work was to study the association between parents' smoking habits and the incidence of respiratory infections and asthma attacks during the preceding 3 months, among children who were attending a kindergarten and elementary school with linkages to an university, in relation to their socioeconomic status, positive response rate to skin tests for allergies, breastfeeding history, atopic disorders among their parents, presence of pets at home and time spent at school.

$\ldots . . . . . . . . \mathrm{METHODS}_{0}$

Design. Descriptive study.

Setting. The study was undertaken at the kindergarten and elementary school of Universidade Federal de São Paulo, a public institution.

Participants. 183 children aged 4 to 9 years

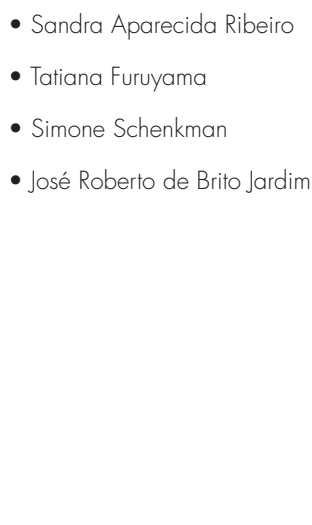

- Tatiana Furuyama

- Simone Schenkman

- José Roberto de Brito Jardim

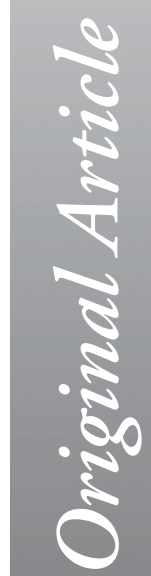

CONTEXT: It has been demonstrated that children exposed to parents who smoke have more respiratory infections and asthma

OBJECTIVE: To study the association of both respiratory infections and asthma attacks with atopy, passive smoking and time spent daily at school, among children aged 4 to 9 years old from a kindergarten and elementary school in the city of São Paulo between May and July of 1996.

TYPE OF STUDY: Descriptive study.

SETTING: A kindergarten and elementary school with linkages to Universidade Federal de São Paulo/ Escola Paulista de Medicina.

PARTICIPANTS: 183 children between 4 and 9 years old

MAIN MEASUREMENTS: A questionnaire consisting of 31 questions was answered by the parents of 183 children, and skin tests for inhaled antigens were performed on 88 children whose parents had given prior agreement for the procedure.

RESULTS: Among the children, 51\% had had respiratory infections during the preceding 3 months and $25.7 \%$ were asthmatic, of whom months and $25.7 \%$ were asthmatic, of whom
$52.1 \%$ had had one or more asthma attacks during the preceding 3 months. Children exposed to passive smoking did not have more respiratory infections or asthma attacks in comparison with those not exposed. We observed a significan association between atopic disorders in parents associalion belween alopic disorders in paren and children who were not exposed to passive smoking. There were also associations between atopic disorders in parents and asthma attacks in their infants, and between such disorders and a higher incidence of respiratory infections in the infants during the preceding 3 months. However, infants during the preceding 3 months. However, the presence of two or more positive skin tests for allergies did not have a correlation with respiratory infections and asthma attacks in this sample. In addition to this, children who studied full time at school did not have a higher occurrence of respiratory infections and asthma attacks.

CONCLUSIONS: The presence of respiratory infections and asthma was associated with atopic parents but not with the presence of two or more positive skin tests for allergies among the children. Also, respiratory infections and asthma attacks were not associated with smoking parents or with the length of time spent by the children at school.

KEY WORDS: Respiratory infections. Asthma. Children. Passive smoking. Allergy 
old, during the months of May through July 1996.

Procedures and main measurements. The parents (or whoever was responsible for the children) filled out a standardized questionnaire consisting of 31 items that inquired about smoking characteristics (such as who smokes, how many people smoke, how many cigarettes per day) and also ex-smokers' characteristics (why they quit the habit). The other covariates considered were the presence of siblings; their ages; whether they were breastfed or not; the frequency of respiratory infections during the last 3 months; the presence of asthma/bronchitis and its characteristics (how many attacks, age of onset of disease and regularity or treatment); and any history of atopic disorders in parents. In the last part, a socioeconomic evaluation was attempted, verifying housing conditions, number of rooms and number of people living in the household, head of family, educational level, family income and number of housing utilities, according to the criteria. ${ }^{10}$

Skin tests for allergies were performed on
88 children, following these steps: 1) sterilization of the forearm using alcohol; 2) scarification using a disposable thin blade, at 8 different places in the forearm; 3) application of 1 drop of allergen (home dust with Dermatophagoides, tobacco, cotton, fungi, dog hair and epithelium), a positive control (histamine) and a negative control (saline); 4) after 20 minutes, the reading was performed: (-) negative test: no papule or erythema in comparison with the negative control, $(-/+)$ dubious test: papule less than $5 \mathrm{~mm}$ with moderate erythema, $(+)$ weakly positive: papule with a diameter of $5 \mathrm{~mm}$ and moderate erythema, $(++)$ mildly positive test: papule $5-10 \mathrm{~mm}$, without pseudopodia and with moderate to strong erythema, $(+++)$ strongly positive papule of 10 $\mathrm{mm}$ or more, with pseudopodia and significant erythema. Tests were considered positive when the readings were weakly, moderately or strongly positive. For the allergy tests, we excluded children under 4 years old and children whose parents had not given permission for the tests to be performed.

This study was approved by the Medical

\begin{tabular}{|c|c|c|c|c|}
\hline Type & Occupation & No. of rooms & $\begin{array}{l}\text { No. of people } \\
\text { living there }\end{array}$ & Ventilation \\
\hline $\begin{array}{l}\text { House } \\
(65.0 \%)\end{array}$ & $\begin{array}{c}\text { own } \\
(55.9 \%)\end{array}$ & $\begin{array}{l}2 \text { to } 4 \\
(44.7 \%)\end{array}$ & $\begin{array}{c}2 \text { to } 4 \\
(66.1 \%)\end{array}$ & $\begin{array}{c}\text { good ventilation } \\
(36.8 \%)\end{array}$ \\
\hline $\begin{array}{l}\text { Apartment } \\
(33.9 \%)\end{array}$ & $\begin{array}{c}\text { rented } \\
(26.3 \%)\end{array}$ & $\begin{array}{c}5 \text { or more } \\
(55.3 \%)\end{array}$ & $\begin{array}{c}5 \text { or more } \\
(33.9 \%)\end{array}$ & $\begin{array}{c}\text { sunny } \\
(35.2 \%)\end{array}$ \\
\hline $\begin{array}{l}\text { Other } \\
(1.1 \%)\end{array}$ & $\begin{array}{c}\text { other } \\
(17.8 \%)\end{array}$ & & & $\begin{array}{c}\text { musty } \\
(28.0 \%)\end{array}$ \\
\hline
\end{tabular}

Table 2. Association between exposure to passive smoking in children and other variables

\begin{tabular}{lccc} 
& \multicolumn{2}{c}{ Passive smoking(\%) } & \\
& Not Exposed & Exposed & $p$ \\
\hline Damp, musty house & & & \\
Yes $(n=30)$ & 11.3 & 6.5 & 0.494 \\
No $(n=138)$ & 46.4 & 35.7 & \\
Pet & & & \\
Yes $(n=65)$ & 23.6 & 15.8 & 0.611 \\
No $(n=100)$ & 33.9 & 26.7 & \\
Breastfeeding & & & \\
Yes $(n=155)$ & 54.2 & 38.1 & 0.379 \\
No $(n=13)$ & 3.6 & 4.2 & \\
Positive skin tests for allergies & & & \\
$(2$ or more) & 16.0 & 12.3 & \\
Yes $(n=23)$ & 44.4 & 27.2 & \\
No $(n=58)$ & & & \\
Parents with atopic disorders & 24.8 & 10.7 & 0.645 \\
Yes $(n=53)$ & 33.6 & 30.9 & \\
No $(n=106)$ & & & \\
Full time at school & 41.3 & 34.8 & 0.397 \\
Yes $(n=118)$ & 14.8 & 9.0 & \\
No $(n=37)$ & & & \\
\hline
\end{tabular}

Ethics Committee of UNIFESP (Universidade Federal de São Paulo).

\section{Statistical methods.}

Pearson Chi-Squared and Fisher exact tests were performed (when at least one expected frequency was less than 5 ). Values of $\mathrm{p}<0.05$ were considered as significant. The odds ratio and $95 \%$ confidence interval were calculated to evaluate the presence of associations between respiratory morbidity in the children and environmental variables. Data were analyzed using the Stata statistical package.

$\ldots \ldots \ldots$ RESULTS

We sent out 255 questionnaires, and 183 responses were returned by the parents or whoever was responsible for the children in the sample (a return rate of 71.8\%). In 37.8\% of the homes, the father and/or mother were smokers and in $47.2 \%$ there was another smoker in the house. Only in $15 \%$ of the houses were there no smokers.

Table 1 shows the different kinds of dwellings occupied by the families, in relation to occupation conditions, number of rooms, number of people living together and ventilation conditions. Most children shared their room with someone else $(88.7 \%)$, and about $40 \%$ of them had pet animals at home, half of which were reported to be dogs.

In relation to the socioeconomic status of the children, according to the ABA/ABIPEME criteria, it was verified that most families were located in the B (35.2\%) and C (50.6\%) classes.

There was a history of breastfeeding in $92.3 \%$ of the responses, and $50 \%$ maintained it for at least the first four months.

With regard to the length of time spent at school each day, $76.1 \%$ of the children attended full-time, while only $23.8 \%$ attended part-time. Children who studied full-time were equally exposed to passive smoking at home, when compared with children that studied part-time. We did not find any statistical difference for the incidence of respiratory infections and asthma in relation to the length of time spent at school.

Eighty-eight skin tests for allergies (on $48.1 \%$ of the sample, of whom $57 \%$ were boys and $43 \%$ were girls) were performed with immediate reading for 6 inhaled allergens. From these tests, $53.4 \%$ did not exhibit a positive response to the tested antigens. The percentage of positive responses to the antigens, separately, were $29.5 \%$ for dog epithelium, $21.5 \%$ for dust, $17 \%$ for cotton, $15.8 \%$ for 
tobacco, $14.8 \%$ for fungi and $12.5 \%$ for wood. Allergic respiratory symptoms in at least one parent were reported in $20.5 \%$ of the sample.

Table 2 shows the statistical associations between exposure to passive smoking and the presence of other variables studied. We found a statistically significant association between parents who had atopic disorders and children not exposed to passive smoking.

Table 3 draws attention to the presence or absence of respiratory problems and asthma attacks during the preceding three months in the studied sample, in relation to unhealthy dwelling places, presence of a pet at home, breastfeeding, presence of two or more positive tests for inhaled antigens, atopic disorders in parents, smoking parents, and the fact that the children attended school full-time. Statistical significance was demonstrated for the associations of atopic disorders in parents with asthma attacks and higher incidence of respiratory infections during the preceding three months.

Parents reported that $51 \%$ of the children had had one or more respiratory infections during the preceding 3 months (including pneumonia, rhinitis, otitis media, sinusitis or pharyngitis). They also reported that $25.7 \%$ of the children had asthma and $52.1 \%$ of the sample had had one or more asthma attacks during the preceding three months.

Figure 1 shows the respiratory infections and asthma attacks in children exposed to tobacco smoke in comparison with those not exposed. However, no statistical significance could be found.

\section{DISCUSSION}

There was quite a high prevalence of children with parents who were active smokers (37.8\%), and the mean cigarette use (10-19 cigarettes/day) was similar to that of the Brazilian population. ${ }^{11}$

With regard to the characteristics of their homes, most families had good housing conditions (less than $28 \%$ of the households were considered damp and/or musty). Moreover, a large number of children shared their bedrooms with only one more person, which decreases exposure to respiratory infections. Their socioeconomic status was also considered satisfactory in comparison with the Brazilian population. In the general population, only $50 \%$ belong to the $\mathrm{B}$ and $\mathrm{C}$ classes, ${ }^{10}$ whereas we noted that among our studied population $86 \%$ belonged to these social classes. This may have decreased the risk of acquiring respiratory infections, even when exposed to tobacco smoke. ${ }^{5,2}$

The positive history of breastfeeding was quite satisfactory $(92.3 \%)$, since it is known that, for offspring who have been breastfed, the occurrence of respiratory infections is reduced, although this is more relevant in early childhood. ${ }^{12}$ Nationwide data has shown an increasing number of breastfed infants over the last few years. In the southeastern region of Brazil, 58\% (47-67\%) of the newborn are breastfed for at least 4 months. ${ }^{12}$ Breastfeeding probably causes a protective biological effect against the irritation from tobacco smoke in the children's respiratory tract. Among the infants that were breastfed for more than 6 months, there was no increase in the risk of lower respiratory tract illnesses caused by the mother's smoking. ${ }^{13}$

Statistical significance was observed in the association between atopic disorders in parents of children with asthma attacks and the presence of respiratory infections during the preceding 3 months, but no association between 2 or more positive skin tests for allergies and asthma could been shown. It is known that both asthma and a greater vulnerability to infections are directly related to atopic disorders and, a familiar genetic component that is next in this causal link.

Today it is known that the offspring of smoking mothers have a higher probability of developing asthma, independent of other factors. ${ }^{7}$ It has been demonstrated that the addition of two other factors, such as atopic disorders and passive exposure to tobacco smoke, greatly increases the risk of triggering respiratory infections in children whose mothers smoke, ${ }^{6}$ especially for infants in their first year of life. ${ }^{14-16}$ A higher incidence of respiratory symptoms among children aged 0 to 10 years who were exposed to passive smoking at home was demonstrated by Botelho et al. ${ }^{17}$.

We found that parents with atopic disorders tried to preserve their kids from passive smoking and they exhibited reduced occurrence

\begin{tabular}{|c|c|c|}
\hline & Respiratory infections & Asthma \\
\hline Damp, musty house & $0.91(0.43-1.93)$ & $1.59(0.71-3.57)$ \\
\hline et & $1.20(0.66-2.20)$ & $0.54(0.26-1.13)$ \\
\hline Breastfeeding & $0.81(0.27-2.40)$ & $0.76(0.23-2.46)$ \\
\hline ositive skin tests for allergies ( 2 or more) & $1.06(0.41-2.72)$ & $0.37(0.11-1.33)$ \\
\hline arents with atopic disorders & $0.40(0.20-0.79)$ & $3.23(1.59-6.6)$ \\
\hline moking parents & $0.87(0.47-1.61)$ & $1.20(0.59-2.41)$ \\
\hline ull time at school & $0.88(0.43-1.84)$ & $1.69(0.66-4.31)$ \\
\hline
\end{tabular}

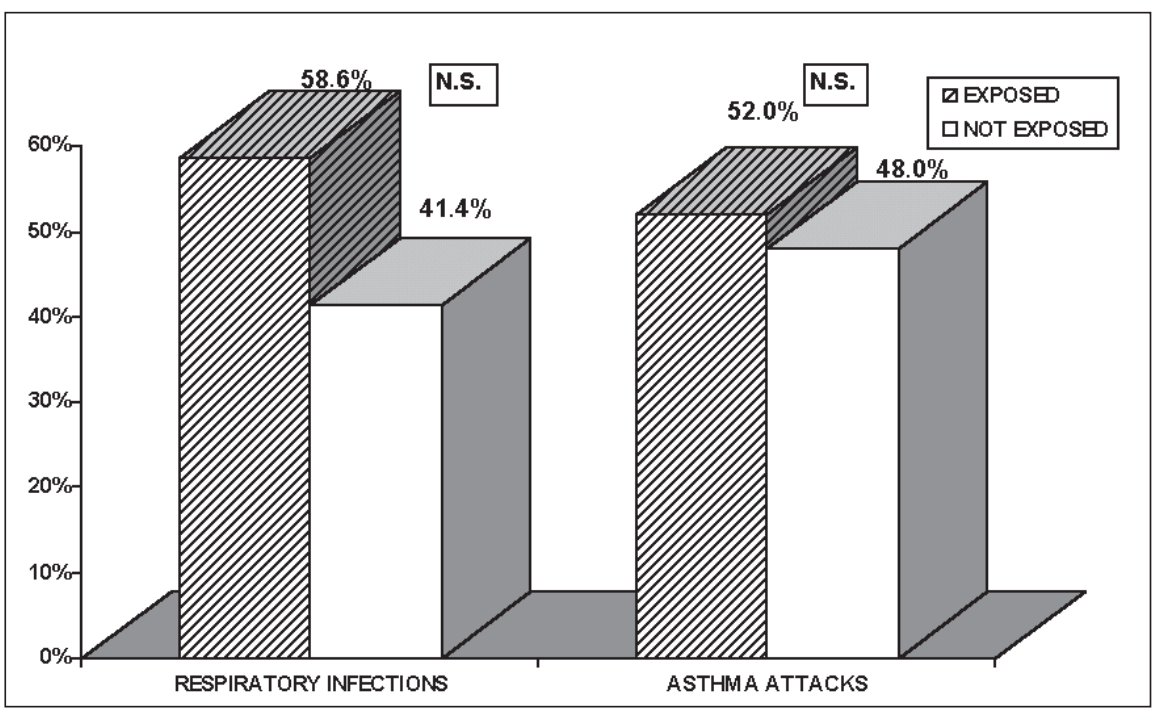

Figure 1. Association between respiratory infections and asthma attacks among children over the preceding 3 months, according to exposure to environmental tobacco smoke. 
of respiratory infections $(\mathrm{OR}=0.40)$, even though the children had had higher episodes of asthma attacks ( $\mathrm{OR}=3.23)$ over the preceding three months (Table 2 and 3 ).

In this research, we did not find an increase in the incidence of respiratory infections and asthma attacks among children exposed to tobacco smoke. This can be explained by the fact that we were dealing with older children with a good socioeconomic status and satisfactory housing, who had been adequately breastfed. The fact that they were away from home for longer periods $(76.1 \%$ were at school all day long) reduced their exposure to envi- ronmental tobacco smoke at home. Moreover, the population studied was small and the time period over which the incidence of respiratory infections and asthma attacks was investigated was limited to only three months, because the longer the period that the parents are asked about, the lower the fidelity of data is. In addition to this, the study was performed in a very polluted city (São Paulo), and this may have contributed to some confusion in the documentation of higher occurrence of respiratory infections and asthma attacks related to passive smoking exposure. Such problems could be clarified with a study conducted using a larger and more representative sample of the population, observed over a prolonged period of time.

$\ldots . . . . .$. CONCLUSIONS $_{0}$

The presence of respiratory infections and asthma attacks were associated with atopic parents but not with the presence of two or more positive skin tests for allergies among the children studied. Also, the presence of respiratory infections and asthma were not associated with parents who smoke, or with studying full-time at school.
1. Chilmoncyk BA, Knight GJ, Pulomaki GE, et al. Environmental tobacco smoke during infancy. Am J Public Health 1990;80:1205-8.

2. Harlap S, Davies AM. Infant admissions to hospital and maternal smoking. Lancet 1974;1:529-36.

3. Ferguson DM, Horwood LJ, Shannon FT, et al. Parental smoking and lower respiratory illness in the first three years of life. J Epidemiol Commun Health 1981;35:180-4.

4. Bonham GS, Wilson, RA. Children's health in families with cigarette smokers. Am J Public Health 1981;71:290-3.

5. Colley JRT, Holland WW, Corkhill RT. Influence of passive smoking and parental phlegm on pneumonia and bronchitis in early childhood. Lancet 1974;2:1031-4.

6. Kraemer MJ, Richardson MA, Weiss NS, et al. Risk factor for persistent middle-ear effusions, otitis media, catarrh, cigarette

\section{PUBLISHING INFORMATION}

Sandra Aparecida Ribeiro, MD, PhD. Assistan Professor in the Departamento de Medicina Preventiva, Universidade Federal de São Paulo/Escola Paulista de Medicina, São Paulo, Brazil.

Tatiana Furuyama. Medical Student, Universidade Federal de São Paulo/Escola Paulista de Medicina, São Paulo, Brazil

Simone Schenkman. Visiting Professor in the Departamento de Medicina Preventiva, Universidade Federal de São Paulo/Escola Paulista de Medicina, São Paulo, Brazil.

José Roberto de Brito Jardim, MD, PhD. Assistant Professor in the Departamento de Medicina, Doenças Respiratórias, Universidade Federal de São Paulo/Escola Paulista de Medicina, São Paulo, Brazil.

Sources of funding: None

Conflict of interest: None

Date of first submission: November 9, 2000

Last received: April 29, 2002

Accepted: April 30, 2002

\section{Address for correspondence}

Sandra Aparecida Ribeiro

Rua Pedro de Toledo, 675 - Vila Clementino

São Paulo/SP - Brasil - CEP 04023-062

Tel. (+55 11) 5571-6934 / 5579-4206

Fax (+55 11) 5549-5159

E-mail: sandrarib@medprev.epm.br smoke exposure, and atopy. JAMA 1983;249:1022-5.

7. Gortmaker AS, Walker DK, Jacobs FH, et al. Parental smoking and the risk of childhood asthma. Am J Public Health 1982;72:574-9.

8. Berkey CS, Ware JH, Dockery DW, et al. Indoor air pollution and pulmonary function growth in pre-adolescent children. Am Epidemiol 1986;123:250-60.

9. Taskin DP, Clark VA, Simmons M, et al. The UCLA population studies of chronic obstructive pulmonary disease. VII Relationship between parental smoking and children's lung function. Am Rev Respir Dis 1984;129:891-7.

10. Sociedade Brasileira de Pesquisa de Mercado. Critério de Classificação Econômica Brasil. No. 2 - São Paulo, Sociedade Brasileira de Pesquisa de Mercado; 1997.

11. Ministério da Saúde: Pesquisa Nacional sobre Estilo de Vida; 1988
12. Venancio SI, Monteiro CA. A tendência da prática da amamentaçăo no Brasil nas décadas de 70 e 80 . Rev Bras Epidemiol. 1998;1(1):40-9.

13. Galve R, Garcia VC, Rubio SFJ, Penascal PE, Jimenez HJM, Martinez BJA. Passive smoking and other risk factors associated to the lower respiratory illnesses in infants. Aten. Primaria 1998; 15:46-51.

14. Rosemberg J. Tabagismo e doenças respiratórias. JBM 1990;59(4):25-44.

15. Rosemberg J. Poluição ambiental tabágica. JBM 1982;43:41-64

16. Rosemberg J. Nocividade à saúde das crianças, conseqüente do tabagismo dos pais. Rev Ass Med Bras 1985;31:2-6.

17. Botelho C, Barbosa LSG, Silva MD, Barros MD. Sintomas respiratórios e tabagismo passivo em crianças. J Pneumol 1987;13(3):136-43.
CONTEXTO: Foi demonstrado que crianças de pais fumantes estão mais predispostas a infecçōes respiratórias e asma.

OBJETIVO: Estudar a associação de infecçōes respiratórias e crises de asma em crianças de quatro a nove anos de idade, matriculadas em uma escola que funciona como pré-escola e $1^{\circ}$ grau em São Paulo, Capital, nos meses de maio a julho de 1996, com presença de atopia, exposição ao fumo passivo e tempo de permanência na escola (parcial ou integral).

TIPO DE ESTUDO: Estudo descritivo.

LOCAL: Pré-escola e de primeiro grau da Universidade Federal de São Paulo.

CASUÍSTICA: 183 crianças, sendo 104 meninos e 79 meninas, entre 4 e 9 anos.

VARIÁVEIS ESTUDADAS: Foi administrado um questionário contendo 31 questôes aos responsáveis pelas crianças e realizados 88 testes cutâneos de alergia para inalantes, nas crianças cujos pais haviam fornecido consentimento prévio.

RESULTADOS: Do total de crianças, 51\% tiveram infecçôes respiratórias nos últimos três meses e $25,7 \%$ eram asmáticas, sendo que $52,1 \%$ delas tiveram uma ou mais crises nos

\section{RESUMO}

últimos três meses. As crianças expostas à fumaça de cigarro no domicílio não tiveram mais infecçôes respiratórias e crises de asma que as não-expostas. A positividade a dois ou mais testes cutâneos de alergia não se correlacionou significantemente à presença de infecçōes respiratórias e crises de asma nas crianças estudadas, embora tenha havido associação estatisticamente significante entre pais com história de atopia e filhos com mais infecçōes respiratórias e/ou crises de asma, assim como pais com história de atopia e filhos com menor exposição à fumaça de cigarro. As crianças com permanência em tempo integral na escola não tiveram maior ocorrência de infecçôes respiratórias e crises de asma.

CONCLUSÃO: A presença de infecçōes respiratórias e crises de asma está associada à atopia dos pais, mas não à presença de positividade a dois ou mais testes cutâneos de alergia nas crianças. Por outro lado, a presença de infecções respiratórias e crises de asma não estiveram associadas com exposição passiva à fumaça de cigarro no domicílio e com tempo de permanência na escola.

PALAVRAS-CHAVE: Infecções respiratórias. Asma. Crianças. Fumo passivo. Alergia. 